\title{
Article \\ Study of CZTSSe-Based Solar Cells with Different ETMs by SCAPS
}

\author{
Lhoussayne Et-taya *, Abdellah Benami * and Touria Ouslimane
}

check for updates

Citation: Et-taya, L.; Benami, A.; Ouslimane, T. Study of CZTSSe-Based Solar Cells with Different ETMs by SCAPS. Sustainability 2022, 14, 1916 https://doi.org/10.3390/su14031916 Academic Editors: Bo Jin, Fei Wang, Feng Lin and Saifur Rahman Sabuj

Received: 27 November 2021 Accepted: 7 January 2022

Published: 8 February 2022

Publisher's Note: MDPI stays neutral with regard to jurisdictional claims in published maps and institutional affiliations.

Copyright: (C) 2022 by the authors. Licensee MDPI, Basel, Switzerland. This article is an open access article distributed under the terms and conditions of the Creative Commons Attribution (CC BY) license (https:// creativecommons.org/licenses/by/ $4.0 /)$.
LM3ER-OTEA, Department of Physics, Faculty of Sciences and Techniques, Moulay Ismail University of Meknes, BP 509 Boutalamine, Errachidia 52000, Morocco; t.ouslimane@edu.umi.ac.ma

* Correspondence: 1.ettaya@edu.umi.ac.ma (L.E.-t.); a.benami@fste.umi.ac.ma (A.B.)

\begin{abstract}
Third-generation thin-film solar cells based on CZTSSe are highly promising because of their excellent optoelectrical properties, earth-abundant, and non-toxicity of their constituent elements. In this work, the performance of CZTSSe-based solar cells with $\mathrm{TiO}_{2}, \mathrm{CdS}$, and $\mathrm{ZnSe}$ as electron transporting materials (ETMs) was numerically investigated using the Solar Cell Capacitance Simulator (SCAPS). The effect of the active layer's thickness and electron affinity, different buffer layers, and the contour plot of the operating temperature versus thickness of the CdS buffer layer were studied. The results show that the optimum power conversion efficiency for $\mathrm{CdS}, \mathrm{TiO}_{2}$, and ZnSe, as the ETMs, is $23.16 \%, 23.13 \%$, and $22.42 \%$, respectively.
\end{abstract}

Keywords: CZTSSe; third-generation thin-film; SCAPS; ETMs; power conversion efficiency

\section{Introduction}

Photovoltaic cells are used to convert large amounts of sunlight to electricity directly. Many studies have recently been conducted to improve the efficiency of thin-film solar cells (TFSCs). Because of their extraordinary properties, TFSCs based on CZTSSe and related materials have attracted increased interest as an absorber layer in third-generation photovoltaic devices. CZTSSe is a p-type conductivity semiconductor with a tunable direct bandgap of $0.95-1.5 \mathrm{eV}$, a large absorption coefficient of over $10^{4} \mathrm{~cm}^{-1}$, a low cost (earth-abundant) and non-toxic element composition [1]. The certified power conversion efficiency (PCE) of CZTSSe was reported to be up to $12.62 \%$, which is lower than that of CIGS and CdTe (23.4\% and $22.1 \%$, respectively), and is far below the theoretical possible efficiency of a single p-n junction calculated by Shockley and Queisser, which is 32.2\% [2]. It should be improved for large-scale photovoltaic applications to overcome the scarcity of In, $\mathrm{Ga}$, and $\mathrm{Te}$, as well as the toxicity of $\mathrm{Cd}[3-7]$.

When a TFSC is illuminated, due to the built-in electrical field at the heterojunction interface between the CZTSSe/ETM, photogenerated electrons travel from p-type CZTSSe absorber layer to n-type ETM and subsequently to the transparent conductive oxide (TCO). The I-V characteristics are used to evaluate the solar cell's performance, and the fill factor (FF) is one of the four important factors that indicate the deviation of the I-V curve from a perfect square. Fill factor is defined as the ratio of maximum power extraction $\left(\mathrm{P}_{\max }\right)$ to the maximum power generation capacity of the device (i.e., the product of $\mathrm{V}_{\mathrm{oc}}$ and $\mathrm{J}_{\mathrm{sc}}$ ), as expressed in Equation (1):

$$
\mathrm{FF}=\frac{\mathrm{P}_{\max }}{\mathrm{V}_{\mathrm{oc}} \times \mathrm{J}_{\mathrm{sc}}}
$$

The PCE is described as the ability to convert sunlight into electricity, which is another very important key parameter that is defined as the ratio between the maximum generate output (Pmax) and the input optical power (Pin), represented as:

$$
\mathrm{PCE}=\frac{\mathrm{P}_{\max }}{\mathrm{P}_{\mathrm{in}}}=\frac{\mathrm{FFxV}_{\mathrm{oc}} \mathrm{xJ}}{\mathrm{P}_{\mathrm{sc}}}
$$


Many studies have been conducted to substitute harmful CdS with alternative materials in kesterite TFSCs. Zhang et al. [8] have designed and simulated CZTSSe-based TFSC with several buffer layers and found that $\operatorname{In}_{2} S_{3}$ is a promising candidate which has great stability and transparency better than CdS. Barkhouse et al. [9] presented experimental research on the $\mathrm{Cd}$-free and band alignments with three different buffer layers and reported the highest PCE for a device with $\mathrm{In}_{2} \mathrm{~S}_{3}$ as an ETM. Zhen-Wu et al. [10] used $\operatorname{In}_{2} \mathrm{~S}_{3} / \mathrm{Zn}(\mathrm{O}, \mathrm{S})$ double buffer layer to increase the carrier concentration in a $\mathrm{Cd}$-free kesterite structured solar cell. $\mathrm{TiO}_{2}$ has been exhibited high refractive index, excellent physical and chemical stability, widely utilized in dye-sensitized solar cells, and is suited as a buffer layer in TFSC. Recently, Bencherif et al. [11] examined the degradation mechanisms in kesterite solar cells with $\mathrm{TiO}_{2}$ as a buffer layer. Although the refractive index is one of the most important physical properties of the thin film [12], SCAPS-1D does not take it into account as input.

As a result, we propose and simulate three device structures with buffer layers of CdS, $\mathrm{TiO}_{2}$, and $\mathrm{ZnSe}$, using SCAPS-1D software. The effect of several parameters on device performance $\left(\mathrm{V}_{\mathrm{oc}}, \mathrm{J}_{\mathrm{sc}}, \mathrm{FF}\right.$, and PCE) was investigated, including thickness, electron affinity, various buffer layers, and temperature.

\section{Methodology}

The schematic cross-section of the TFSC structure used in this study is shown in Figure 1. The device under investigation consists of a Mo back contact that serves as the positive terminal, the p-CZTSSe active layer in which electron-hole pairs are generated after absorption of incident photons. Following that, $\mathrm{CdS}, \mathrm{TiO}_{2}$, or $\mathrm{ZnSe}$ ETM was used to align the absorber and the window layer. The buffer layer is then stacked with $\mathrm{i}-\mathrm{ZnO}$, which is capped by a $\mathrm{ZnO}$ : Al window layer that acts as a TCO to collect charges.

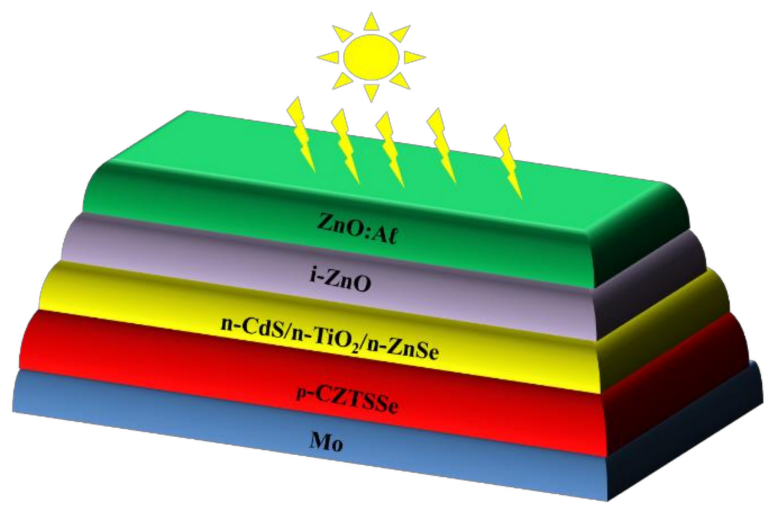

Figure 1. Structure of CZTSSe cell.

SCAPS is a program developed at the University of Gents in Belgium [6]. It is widely used for the simulation of various types of TFSCs. The SCAPS simulation results have been reported to agree well with the corresponding experimental results, which provides a convincing reason to use them in this study [5]. The software is based on solving the fundamental semiconductor Equations (3)-(5), namely the Poisson equation and the hole and electron continuity equations. It computes the band diagram in a steady-state, the recombination profile, and carrier transport in one dimension. The equations are shown below $[5,13,14]$.

$$
\begin{gathered}
\frac{\partial^{2} \Psi}{\partial x^{2}}+\frac{\mathrm{q}}{\varepsilon}\left[\mathrm{p}(\mathrm{x})-\mathrm{n}(\mathrm{x})+\mathrm{N}_{\mathrm{D}}-\mathrm{N}_{\mathrm{A}}+\rho_{\mathrm{p}}-\rho_{\mathrm{n}}\right]=0 \\
\frac{1}{\mathrm{q}} \frac{\mathrm{dJ} \mathrm{p}}{\mathrm{dx}}=\mathrm{G}_{\mathrm{op}}(\mathrm{x})-\mathrm{R}(\mathrm{x}) \\
\frac{1}{\mathrm{q}} \frac{\mathrm{dJ}}{\mathrm{dx}}=-\mathrm{G}_{\mathrm{op}}(\mathrm{x})+\mathrm{R}(\mathrm{x})
\end{gathered}
$$


Here, $\mathrm{q}$ is the electron's charge, $\varepsilon$ is the dielectric constant, $\Psi$ is the electrostatic potential and, $N_{A}\left(N_{D}\right)$ is the density of acceptor-like (donor-like). $p(n), \rho_{p}\left(\rho_{n}\right)$, and $J_{p}\left(J_{n}\right)$ are hole (electron) concentration, hole (electron) density, and hole (electron) current density, respectively. $R$ is the net recombination from direct and indirect recombination, and $G_{o p}$ is the optical generation rate.

The values of the device and material parameters used in this study are taken from the literature, experimental, theory, and reasonable estimation [13-15] and are summarized in Table 1.

Table 1. Parameters used in the simulation [5,10-17].

\begin{tabular}{ccccccc}
\hline Parameters & ZnO:Al & i-Zno & n-TiO & n-ZnSe & n-CdS & p-CZTSSe \\
\hline $\mathrm{d}(\mathrm{nm})$ & 200 & 50 & 50 & 50 & Variable & Variable \\
$\mathrm{E}_{\mathrm{g}}(\mathrm{eV})$ & 3.3 & 3.3 & 3.26 & 2.90 & 2.4 & Variable \\
$\chi(\mathrm{eV})$ & 4.4 & 4.4 & 4.2 & 4.02 & 4.2 & Variable \\
$\mathcal{E}(\mathrm{eV})$ & 9 & 9 & 10 & 10 & 10 & 13.6 \\
$\mathrm{~N}_{\mathrm{c}}\left(\mathrm{cm}^{-3}\right)$ & $2.2 \times 10^{18}$ & $2.2 \times 10^{18}$ & $2.2 \times 10^{18}$ & $2.2 \times 10^{18}$ & $2.2 \times 10^{18}$ & $2.2 \times 10^{18}$ \\
$\mathrm{~N}_{\mathrm{v}}\left(\mathrm{cm}^{-3}\right)$ & $1.8 \times 10^{19}$ & $1.8 \times 10^{19}$ & $1.8 \times 10^{19}$ & $1.8 \times 10^{19}$ & $1.8 \times 10^{19}$ & $1.8 \times 10^{19}$ \\
$\mathrm{~V}_{\text {the }}(\mathrm{cm} / \mathrm{s})$ & $10^{7}$ & $10^{7}$ & $10^{7}$ & $10^{7}$ & $10^{7}$ & $10^{7}$ \\
$\mathrm{~V}_{\text {thp }}(\mathrm{cm} / \mathrm{s})$ & $10^{7}$ & $10^{7}$ & $10^{7}$ & $10^{7}$ & $10^{7}$ & $10^{7}$ \\
$\mu \mathrm{n}\left(\mathrm{cm}^{2} / \mathrm{Vs}\right)$ & $10^{2}$ & $10^{2}$ & $10^{2}$ & 25 & $10^{2}$ & $10^{2}$ \\
$\mu \mathrm{h}\left(\mathrm{cm}^{2} / \mathrm{Vs}\right)$ & 25 & 25 & 25 & 100 & 25 & 25 \\
$\mathrm{~N}_{\mathrm{D}}\left(\mathrm{cm}^{-3}\right)$ & $10^{20}$ & $10^{19}$ & $10^{18}$ & $10^{18}$ & $10^{18}$ & 0 \\
$\mathrm{~N}_{\mathrm{A}}\left(\mathrm{cm}^{-3}\right)$ & 0 & $10^{19}$ & 0 & 0 & 0 & $10^{18}$ \\
$\alpha\left(\mathrm{cm}^{-1}\right)$ & {$[5]$} & {$[5]$} & {$[15]$} & {$[15]$} & {$[5]$} & {$[5]$} \\
\hline
\end{tabular}

The device was illuminated with an AM 1.5 spectrum with a light power of $1000 \mathrm{~W} / \mathrm{m}^{2}$. This study's shunt and series resistances were $600 \Omega / \mathrm{cm}^{2}$ and $1.5 \Omega / \mathrm{cm}^{2}$, respectively [5].

\section{Results and Discussion}

\subsection{Energy Level and Band Alignment}

Figure 2a depicts the energy levels of different layers and the mechanism of charge extraction through various device interfaces. When the device is exposed to sunlight, electron-hole pairs are generated in the absorber and transported in the opposite directions toward front and back contact, respectively.
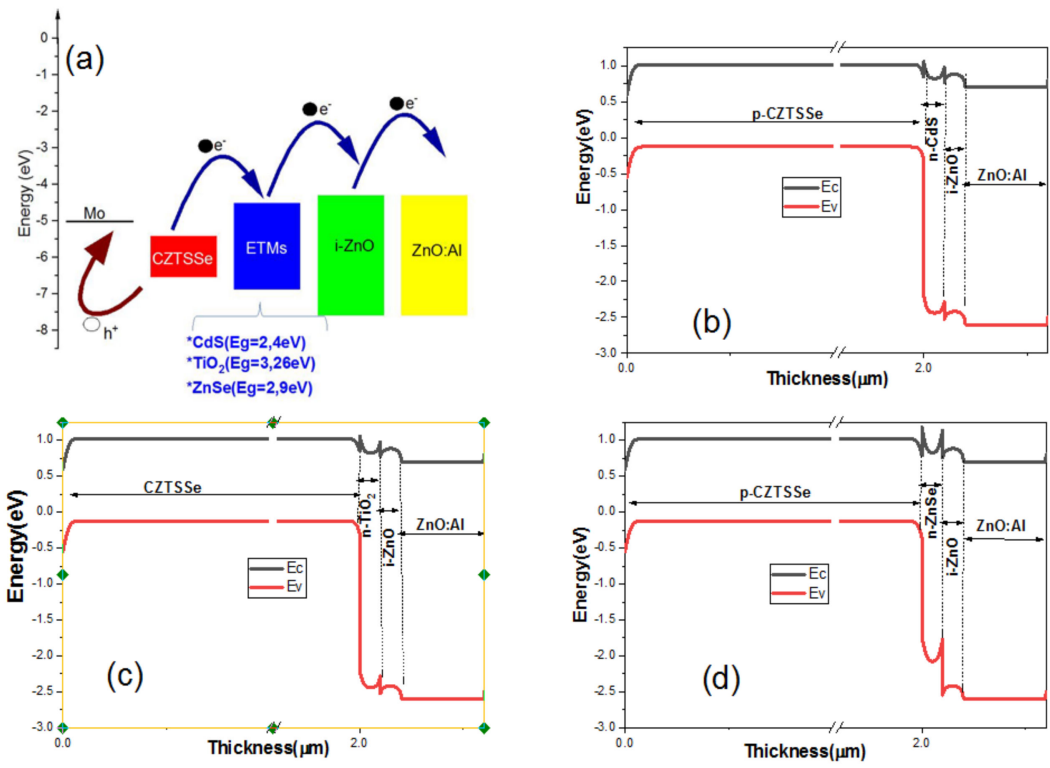

Figure 2. (a) Energy level before forming heterojunction, energy band diagram of (b) CZTSSe/CdS, (c) CZTSSe $/ \mathrm{TiO}_{2}$, and (d) CZTSSe/ZnSe based solar cell. 
The most important physical parameter that governs the transport of photo-generated carriers at the CZTSSe/ETM heterojunction interface and influences the performance of solar cells is band alignment. The difference in electron affinity between the absorber and the buffer layer impacts the alignment of the hetero-interface band. Achieving a highefficiency solar cell requires a spike-like conduction band offset of $0-0.4 \mathrm{eV}$. CZTSSe has an electron affinity that ranges between 4.35 and $4.5 \mathrm{eV}$, while $\mathrm{CdS}, \mathrm{TiO}_{2}$, and $\mathrm{ZnSe}$ have $4.2 \mathrm{eV}, 4.2 \mathrm{eV}$, and $4.02 \mathrm{eV}$, respectively. Figure $2 \mathrm{~b}-\mathrm{d}$ depicts the energy band diagram of CZTSSe/ETM, with an absorber electron affinity of $4.41 \mathrm{eV}$. It can be seen that the difference between CZTSSe electron affinity and those of ETM is in the range from 0.21 to $0.39 \mathrm{eV}$, so at the junction absorber/ETM bottom of the conduction band bend upward by 0.21 to $0.39 \mathrm{eV}$ from CZTSSe to ETM.

\subsection{Effect of the CZTSSe Absorber Layer's Thickness}

The absorber layer is crucial in enhancing device efficiency. In this context, simulations with $\mathrm{CdS}, \mathrm{TiO}_{2}$, and Znse buffer layers were used to examine the solar cell's performance in terms of the CZTSSe absorber layer. The thickness of the CZTSSe absorber layer varied from 500 to $3000 \mathrm{~nm}$, with a fixed ETM thickness of $50 \mathrm{~nm}$. As the thickness of the CZTSSe absorber layer increases, more photons are absorbed, resulting in more electron-hole pairs $[5,14]$. Figure $3 a-d$ depicts the variation of photovoltaic parameters $\left(\mathrm{V}_{\mathrm{oc}}, \mathrm{J}_{\mathrm{sc}}, \mathrm{FF}, \mathrm{PCE}\right)$ as a function of CZTSSe absorber layer thickness in which the result is in good agreement with Beer-Lamberts law. Table 2 summarizes the changes in all device parameters caused by various ETMs for absorber thicknesses of 500 and $3000 \mathrm{~nm}$. According to the findings, $\mathrm{J}_{\mathrm{sc}}$ rises as absorber thickness increases. A thinner absorber layer absorbs fewer photons, while a thicker absorber layer absorbs more photons and produces more electron-hole pairs. As the formation of electron-hole pairs in the absorber layer rises, the $\mathrm{J}_{\mathrm{sc}}$ will rise. The following continuity equation is used in SCAPS-1D software to determine the relationship between the $\mathrm{V}_{\mathrm{oc}}$ and current density $\mathrm{J}_{\mathrm{sc}}$.

$$
\mathrm{V}_{\mathrm{oc}}=\frac{\mathrm{kT}}{\mathrm{q}}\left[\ln \left(\frac{\mathrm{J}_{\mathrm{sc}}}{\mathrm{J}_{0}}+1\right)\right]
$$

where $\frac{\mathrm{kT}}{\mathrm{q}}$ is thermal voltage, $\mathrm{J}_{0}$ is the reverse saturation current density.
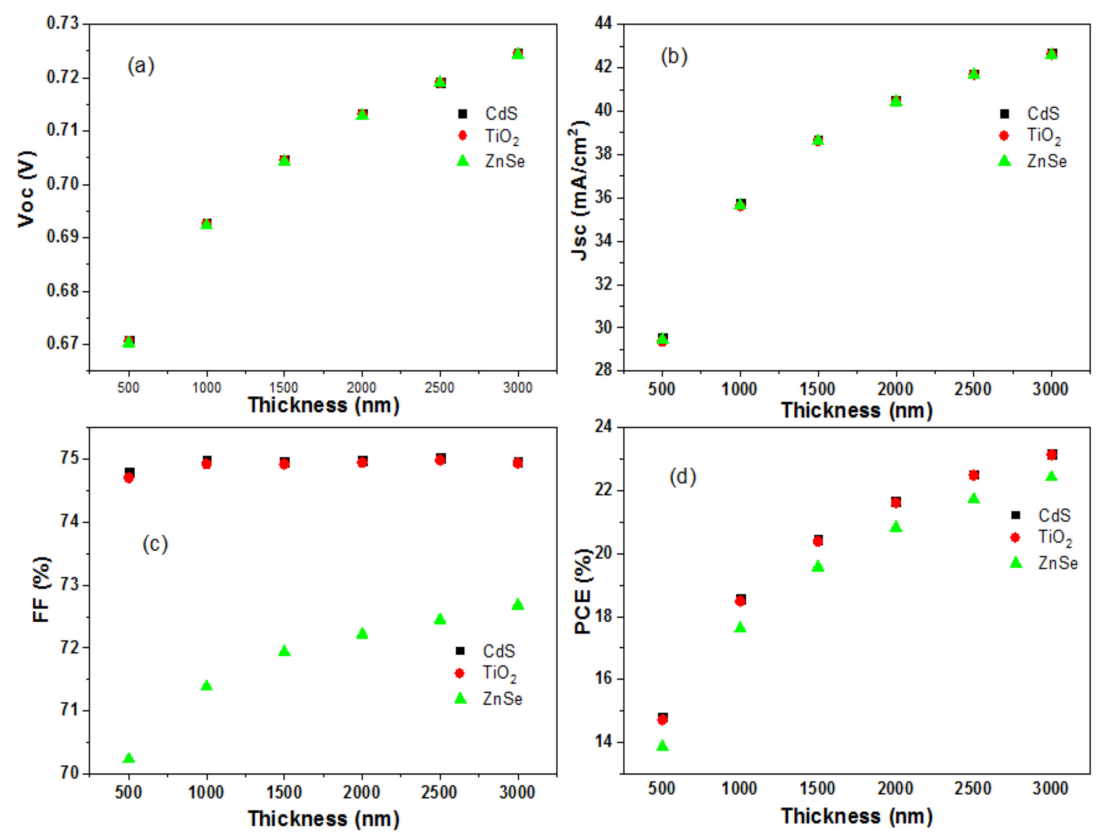

Figure 3. Effect of various thicknesses of CZTSSe absorber layer on photovoltaic parameters (a) Voc, (b) Jsc, (c) FF and (d) PCE with different ETMs. 
Table 2. The effect of the ETM layer on the photovoltaic parameters for absorber thicknesses of 500 and $3000 \mathrm{~nm}$.

\begin{tabular}{cccccc}
\hline ETM & CZTSSe Thickness $(\mathbf{n m})$ & $\mathbf{V}_{\mathbf{o c}} \mathbf{( V )}$ & $\mathbf{J}_{\mathbf{s c}}\left(\mathbf{m A} \mathbf{\mathbf { c m } ^ { 2 }}\right)$ & $\mathbf{F F} \mathbf{( \% )}$ & PCE (\%) \\
\hline \multirow{2}{*}{$\mathrm{CdS}$} & 500 & 0.67 & 29.55 & 74.78 & 14.82 \\
& 3000 & 0.72 & 42.64 & 74.96 & 23.16 \\
\hline \multirow{2}{*}{$\mathrm{TiO}_{2}$} & 500 & 0.67 & 29.37 & 74.7 & 14.72 \\
& 3000 & 0.72 & 42.61 & 74.93 & 23.13 \\
\hline \multirow{2}{*}{$\mathrm{ZnSe}$} & 500 & 0.67 & 29.45 & 70.24 & 13.87 \\
& 3000 & 0.72 & 42.58 & 72.68 & 22.42 \\
\hline
\end{tabular}

\subsection{Effect of Electron Affinity of Absorber Layer}

Figure $4 \mathrm{a}-\mathrm{d}$ depicts the effect of absorber layer CZTSSe electron affinity on photovoltaic cell performance. The electron affinity of the absorber layer varied from $4.35 \mathrm{eV}$ (CZTSe) to $4.5 \mathrm{eV}$ (CZTS) as extracted from the reference [5]. We can see that $\mathrm{V}_{\mathrm{OC}}, \mathrm{FF}$, and PCE values increase until a maximum value of $\chi=4.41 \mathrm{eV}$ is reached, and then decrease with a further increase of $\chi$. On the other hand, $\mathrm{J}_{\mathrm{sc}}$ decreases linearly with the electron affinity. The CZTSSe device's band offset is crucial in influencing charge carrier recombination at the interfaces. The initial increment in efficiency can be attributed to perfect band alignment, whereas the subsequent drop can be attributed to an increase in barrier height, which makes it difficult to collect photo-generated charge carriers.

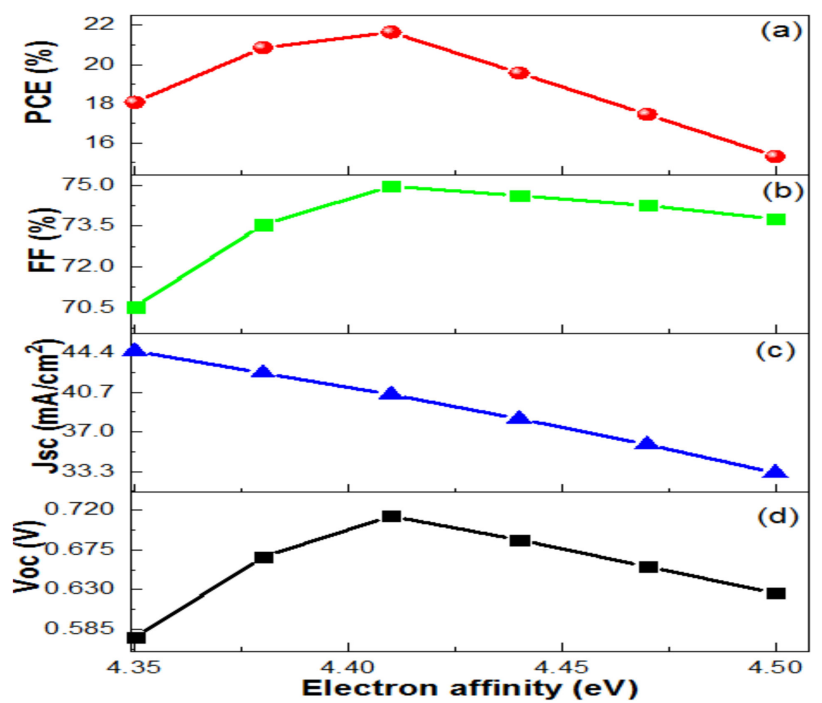

Figure 4. Variation of (a) PCE, (b) FF, (c) $\mathrm{J}_{\mathrm{Sc}}$, and (d) $\mathrm{V}_{\mathrm{Oc}}$ as a function of CZTSSe electron affinity.

\subsection{Impact of the CdS Buffer Layer Thickness and Temperature Contour Plot}

The buffer layer and operating temperature are well known to affect the performance of solar cells. As a consequence, the CdS buffer layer thickness and operating temperature have been increased to improve performance, from 30 to $80 \mathrm{~nm}$ and from 240 to $320 \mathrm{~K}$, respectively. The thickness of CdS has little effect on the output characteristics, as illustrated in Figure 5. Based on modeling results for $50 \mathrm{~nm}$ thickness of CdS buffer layer at ambient temperature, the best efficiency is obtained at $21.65 \%$, and the efficiency remains constant. Temperature increases, on the other hand, cause a drop in PCE, FF, and $\mathrm{V}_{\mathrm{oc}}$ while increasing $\mathrm{J}_{\mathrm{sc}}$. The energy of electrons increases as the temperature rises, and the band gap of the material narrows. Electrons with a substantial amount of energy recombine with other holes. As a result, the rate of internal carrier recombination increases, resulting in a loss in efficiency [5]. 

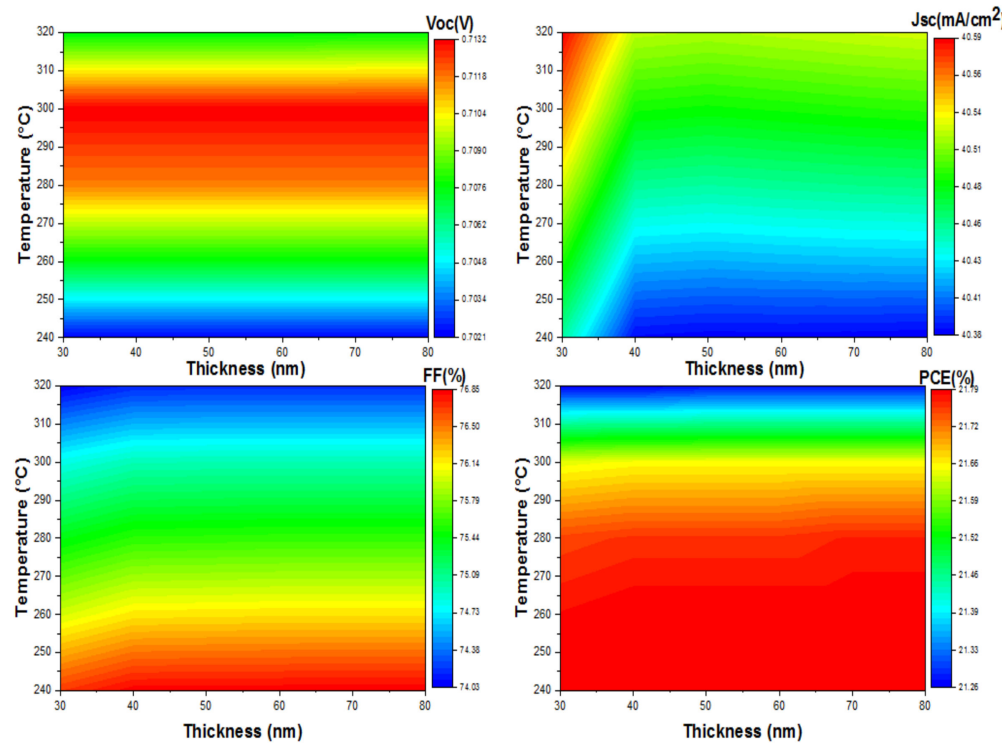

Figure 5. Contour plot of solar cell output as a function of the CdS buffer layer thickness and operating temperature.

\section{Conclusions}

In this paper, numerical simulations of CZTSSe-based TFSCs were performed using the SCAPS-1D software. Three different solar cells with buffer layers of $\mathrm{CdS}, \mathrm{TiO}_{2}$, and $\mathrm{ZnSe}$ were investigated in order to find a safe alternative to the toxic CdS. Maximum PCE of CZTSSe solar cells with $\mathrm{CdS}, \mathrm{TiO}_{2}$, and $\mathrm{ZnSe}$ buffer layers was predicted to be $23.16 \%$, $23.13 \%$, and $22.42 \%$ at ambient temperature and $3000 \mathrm{~nm}$ active layer, respectively. As a result, $\mathrm{TiO}_{2}$ may be a viable choice for producing and manufacturing low-cost, highefficiency Cd-free CZTSSe heterojunction solar cells.

Author Contributions: Conceptualization, L.E.-t.; methodology, L.E.-t.; software, L.E.-t. and T.O.; validation, L.E.-t.; formal analysis, L.E.-t. and A.B.; investigation, L.E.-t. and A.B.; resources, L.E.-t. and T.O.; data curation, L.E.-t.; writing-original draft preparation, L.E.-t.; writing-review and editing, A.B.; visualization, L.E.-t. and A.B.; supervision, A.B. All authors have read and agreed to the published version of the manuscript.

Funding: This research received no external funding.

Institutional Review Board Statement: Not applicable.

Informed Consent Statement: Not applicable.

Data Availability Statement: The data are available on request from the corresponding author.

Acknowledgments: The authors are very much grateful to Burgelman for providing SCAPS-1D software.

Conflicts of Interest: The authors declare no conflict of interest.

\section{Nomenclature}

$\begin{array}{ll}\mathrm{d} & \text { Thickness } \\ \mathrm{E}_{\mathrm{g}} & \text { Bandgap } \\ \chi & \text { Electron Affinity } \\ \varepsilon & \text { Dielectric permittivity } \\ \mathrm{N}_{\mathrm{c}} / \mathrm{N}_{\mathrm{v}} & \text { Density of states in CB/VB } \\ \mathrm{V}_{\text {the }}-/ \mathrm{V}_{\text {thp }} & \text { Thermal velocity of electron/hole } \\ \mu_{\mathrm{n}} / \mu_{\mathrm{h}} & \text { Electron/Hole mobility } \\ \mathrm{N}_{\mathrm{D}} / \mathrm{N}_{\mathrm{A}} & \text { Donor/Acceptor density } \\ \alpha & \text { Absorption coefficient }\end{array}$




\section{References}

1. Altamura, G.; Vidal, J. Impact of minor phases on the performances of CZTSSe thin-film solar cells. Chem. Mater. 2016, 28, 3540-3563. [CrossRef]

2. Shockley, W.; Queisser, H.J. Detailed balance limit of efficiency of $p-n$ junction solar cells. J. Appl. Phys. 1961, 32, 510-519. [CrossRef]

3. Enayati Maklavani, S.; Mohammadnejad, S. The impact of the carrier concentration and recombination current on the $\mathrm{p}^{+} \mathrm{pn}$ CZTS thin film solar cells. Opt. Quantum Electron. 2020, 52, 279. [CrossRef]

4. Gupta, G.K.; Dixit, A. Theoretical studies of single and tandem $\mathrm{Cu}_{2} \mathrm{ZnSn}(\mathrm{S} / \mathrm{Se})_{4}$ junction solar cells for enhanced efficiency. Optical Materials. Opt. Mater. 2018, 82, 11-20. [CrossRef]

5. Et-taya, L.; Ouslimane, T.; Benami, A. Numerical analysis of earth-abundant $\mathrm{Cu}_{2} \mathrm{ZnSn}\left(\mathrm{S}_{\mathrm{x}} \mathrm{Se}_{1-\mathrm{x}}\right)_{4}$ solar cells based on Spectroscopic Ellipsometry results by using SCAPS-1D. Sol. Energy 2020, 201, 827-835. [CrossRef]

6. $\quad$ Benzetta, A.E.; Abderrezek, M.; Djeghlal, M.E. Boosting CZTSSe Solar Cell Efficiency by Back Surface Field Layer. J. Nano-Electron. Phys. 2018, 10, 6-10. [CrossRef]

7. Burgelman, M.; Decock, K.; Khelifi, S.; Abass, A. Advanced electrical simulation of thin film solar cells. Thin Solid Films 2013, 535, 296-301. [CrossRef]

8. Zhang, W.C.; Tang, J.Y.; Niu, Y.H.; Huang, R.; Chen, L.; Jiang, M.Y. Study the best ratio of S and Se in CZTSSe solar cells with nontoxic buffer layer. J. Renew. Sustain. Energy 2021, 13, 033701. [CrossRef]

9. Barkhouse, D.A.; Haight, R.; Sakai, N.; Hiroi, H.; Sugimoto, H.; Mitzi, D.B. Cd-free buffer layer materials on $\mathrm{Cu}_{2} \mathrm{ZnSn}\left(\mathrm{S}_{\mathrm{x}} \mathrm{Se} \mathrm{e}_{1-\mathrm{x}}\right)_{4}$ : Band alignments with $\mathrm{ZnO}, \mathrm{ZnS}$, and $\mathrm{In}_{2} \mathrm{~S}_{3}$. Appl. Phys. Lett. 2012, 100, 193904. [CrossRef]

10. Jiang, Z.W.; Gao, S.S.; Wang, S.Y.; Wang, D.X.; Gao, P.; Sun, Q.; Zhou, Z.Q.; Liu, W.; Sun, Y.; Zhang, Y. Insight into band alignment of $\mathrm{Zn}(\mathrm{O}, \mathrm{S}) / \mathrm{CZTSe}$ solar cell by simulation. Chin. Phys. B 2019, 28, 048801. [CrossRef]

11. Bencherif, H.; Dehimi, L.; Mahsar, N.; Kouriche, E.; Pezzimenti, F. Modeling and optimization of CZTS kesterite solar cells using $\mathrm{TiO}_{2}$ as efficient electron transport layer. Mater. Sci. Eng. B 2022, 276, 115574. [CrossRef]

12. Khan, F.; Baek, S.H.; Kim, J.H. Influence of oxygen vacancies on surface charge potential and transportation properties of Al-doped $\mathrm{ZnO}$ nanostructures produced via atomic layer deposition. J. Alloys Compd. 2017, 709, 819-828. [CrossRef]

13. Benami, A. Effect of CZTS parameters on photovoltaic solar cell from numerical simulation. J. Energy Power Eng. 2019, 13, 32-36.

14. Rahman, M.A. Enhancing the photovoltaic performance of Cd-free $\mathrm{Cu}_{2} \mathrm{ZnSnS}_{4}$ heterojunction solar cells using $\mathrm{SnS} \mathrm{HTL}$ and $\mathrm{TiO}_{2}$ ETL. Sol. Energy 2021, 215, 64-76. [CrossRef]

15. Fujiwara, H.; Collins, R.W. Spectroscopic Ellipsometry for Photovoltaics; Springer: Cham, Switzerland, 2018.

16. Verma, A.; Khan, F.; Kumar, D.; Kar, M.; Chakravarty, B.C.; Singh, S.N.; Husain, M. Sol-gel derived aluminum doped zinc oxide for application as anti-reflection coating in terrestrial silicon solar cells. Thin Solid Films 2010, 518, 2649-2653. [CrossRef]

17. Khan, F.; Baek, S.H.; Mobin, A.; Kim, J.H. Enhanced performance of silicon solar cells by application of low-cost sol-gel-derived Al-rich ZnO film. Solar Energy 2014, 101, 265-271. [CrossRef] 